\title{
DIE NUWE GRONDWET \\ VAN SUID-AFRIKA
}

ALGEMENE BEGINSELS EN IMPLIKASIES

\section{Referaat gelewer by die verplegingsforum van die S.A. Verpleegstersvereniging, Maart 1984}

\section{PROF W.P. ESTERHUYSE \\ Departement Filosofie, Universiteit van Stellenbosch}

\section{INLEIDING}

$\mathrm{Na}$ die intensiewe referendumveldtog van verlede jaar is dit met ' $n$ mate van huiwering dat hier oor die nuwe grondwet gepraat word. Dit is immers so dat wanneer mense deur radio, televisie, koerante en rondreisende sprekers oor 'n bepaalde onderwerp gebombardeer is, 'n volgende persoon sy storie moet ken as hy nie sy gehoor aan die slaap wil sus nie.

Dit word veronderstel dat $\mathrm{u}$ met sekere basiese feite aangaande die konstitusie bekend is. Hier word die volgende beoog:

- Eerstens om op 'n paar basiese beginsels wat in die nuwe konstitusie vervat is te let.

- Tweedens om die aandag te vestig op sommige van die meganismes waarvoor die nuwe konstitusie voorsiening maak en wat daarop gerig is om tot die formuleer van beleid te kan kom.

- Derdens om te let op moontlike implikasies van die nuwe konstitusie vir politieke prosesse in ons land.

\section{Baslese beginsels van die nuwe konstitusie}

Baie mense se voorbehoude teen die nuwe konstitusie hang met iets tipies mensliks saam, naamlik om dit wat nuut is en nog nie in praktyk getoets is nie, met 'n mate van wantroue te bejeën. Veral in die politiek is mense geneig om voorkeur aan die bekende te gee.

Soos bekend, is die nuwe konstitusie 'n poging om van die Westminsterstelsel weg te breek. Hierdie

\section{SUMMARY}

The new constitution of the RSA is an attempt to break away from the Westminster system of government. A few important basic principles include a distinct separation between executive and legislative power, group representation, participation in common affairs, and the principle of consensus.

The constitution provides a number of important mechanisms to enable the formulation of policy. These mechanisms include the position of the President, the President's Council and the permanent collective committees.

One of the implications of the new constitution is that government departments for own affairs for a particular population group can only be headed by a Minister of the same population group. Other implications are decentralisation of power to regional levels, that we are entering an era of collective bargaining in politics and that structures for co-operation and mutual discussion will have to be be created.

A constitution can be likened to the rules of a game. How the game is played, however, depends on the attitude of the players.

stelsel, wat veral sedert Uniewording (1910) die Suid-Afrikaanse Staat bedien het, het onder andere die volgende eienskappe:

- Die kompetisie vir politieke mag vind plaas op die beginsel van die wenner neem alles. Indien party $\mathrm{X}$ die meerderheid setels in ' $\mathrm{n}$ verkiesing wen, word dit ook die regerende party. Hierdie kompetisie vind plaas op die basis van 'n gemeenskaplike kieserslys. Minderheidsgroepe word nie in aanmerking geneem nie. Dit spreek vanself dat hierdie stelsel veral vir samelewings wat redelik homogeen is, ontwerp is.

- Die Westminsterstelsel word ook die parlementêre stelsel van regering genoem. Dit impliseer onder andere dat die uitvoerende gesag verantwoordelik is aan die Parlement en dat die Staatspresident slegs nominale gesag het. In hierdie stelsel speel die Eerste
Minister met sy kabinet 'n deurslaggewende rol.

Hoewel die nuwe kostitusie nie volledig met Westminster breek nie, kan die volgende daarvan gesê word.

\section{Skeiding tussen uitvoerende en wetgewende gesag}

Daar vind 'n bepaalde skeiding tussen die uitvoerende gesag (dit is die President met sy kabinet) en die wetgewende gesag (die Parlement) plaas. Ons sal nie meer 'n Eerste Minister hê nie, maar slegs leiers van kamers en ministersrade vir die verskillende kamers. Ons kan selfs aanvaar dat die leiers van kamers, wat sal optree as die voorsitters van die onderskeie ministersrade, nie dieselfde politieke belangrikheid sal hê as die huidige Eerste Minister nie. Die amp wat polities belangrik sal wees, is dié van die President. 


\section{Groepsverteenwoordiging}

In die nuwe konstitusie word die bestaan van groepe en hulle reg tot selfbeskikking as 'n gegewe aanvaar. Daarom is 'n sentrale beginsel van die nuwe konstitusie die kwessie van groepverteenwoordiging. Anders gestel: dit word aanvaar dat Suid-Afrika 'n land van minderhede is en dat die konstitusie daarvoor voorsiening moet maak.

Die wyse waarop dit gedoen word, is deur die daarstelling van drie kamers vir een en dieselfde Parlement. Hierdie kamers het jurisdiksie oor sake wat die betrokke groep as groep raak en sal hanteer word deur die kamers en hulle Ministersrade.

Volgens die konstitusie word dit as eie sake gedefinieer en sluit onder andere die volgende in: opvoeding, welsyn, kultuur, gemeenskapsontwikkeling, gesondheid en plaaslike bestuur.

Dit is belangrik om daarop te let dat die kompetisie vir mag in die kamers sal plaasvind op die beginsel van Westminster: die wenner neem alles.

\section{Medeseggenskap}

'n Ander beginsel wat aanvaar word, hang saam met die gegewe dat die bevolkingsgroepe dieselfde vaderland deel, of te wel die feit dat die RSA nie 'n Wit republiek is nie.

Hierdie beginsel is die beginsel van medeseggenskap in gemeenskaplike sake, dit wil sê sake wat al drie die bevolkingsgroepe raak. Dit spreek immers vanself dat groepe wat dieselfde vaderland deel ook gedeelde belange het - byvoorbeeld buitelandse sake, verdediging en finansiering. Daarom het hulle ook die reg om seggenskap in die hantering van hierdie belange te hê.

Die President en die kabinet, waarvan hy die voorsitter is en wat hy ook aanwys, is die plek waar hierdie belange hanteer sal word, met dien verstande dat wetgewing oor gemeenskaplike sake ook deur die drie kamers gevoer sal word. Ontstaan daar 'n geskil oor wat as gemeenskaplike belang sal deurgaan, berus die beslissingsbevoegdheid by die President. Sy beslissing is finaal.

\section{Konsensus}

'n Vierde beginsel wat in die nuwe grondwet ingebou is, is die beginsel van konsensus. Hierdie beginsel stipuleer dat politieke besluitneming, veral wat gemeenskaplike belange betref, sover as wat moontlik is op die soeke na ooreenkoms en eenstemmigheid sal berus.

Hierdie beginsel is in ' $n$ sekere sin nie nuut nie. In ons huidige stelsel word reeds voorsiening gemaak vir komitees wat oor sekere sake, soos byvoorbeeld verdediging, ooreenkoms en eenstemmigheid sal soek. Tog is daar wel ' $n$ belangrike verskil.

In die Westminsterstelsel word die styl van politiek gekenmerk deur konflik. Hierdie konflik hang onder andere saam met die feit dat die partye wat in die Parlement verteenwoordig is, hulle eie beleidstandpunte het, dit propageer en die ander partye opponeer. Binne die onderskeie kamers sal ons nog steeds iets hiervan sien.

Deur egter die soeke na konsensus voorop te stel, veral wat gemeenskaplike belange betref, word die styl van ons politiek in dié sin verander dat daar meer gelet sal word op punte van ooreenkoms en gemeenskaplikheid in belange as wat daar op verskille gekonsentreer sal word.

Dit spreek ook vanself dat hierdie beginsel veronderstel dat intensiewe onderhandelinge oor veral gemeenskaplike belange gevoer sal word. Die dae van eensydige aankondigings en besluite wat êrens deur een belanghebbende party geneem is, is vir goed verby. Partypolitiek sal daarom 'n laere prioriteit as groepspolitiek kry.

\section{BELANGRIKE \\ MEGANISMES}

Melding is reeds gemaak van die President se posisie en die drie kamers waaruit die nuwe Parlement sal bestaan. Ook dat die President sy eie kabinet sal hê en dat elke kamer oor 'n Ministersraad sal beskik. Laasgenoemde sal die gesagsbevoegdheid hê om eie sake te hanteer. So byvoorbeeld sal plaaslike bestuur onder die gesagsbevoegdheid van die kamer en sy Ministersraad val wat die bepaalde bevolkingsgroep vir wie die plaaslike bestuur ingestel is, se sake behartig.

In die verband is dit belangrik om te meld dat die onderskeie kamers nie die mag sal hê om belastings te hef of om lenings aan te gaan nie.

Daar sal elke jaar vier begrotings by die Parlement ingedien word, te wete 'n algemene begroting en drie begrotings wat voorsiening maak vir die administrasie van elke bevolkingsgroep se eie sake.

Die algemene begroting sal volgens 'n formule fondse aan elke kamer toedeel - op dieselfde wyse as wat staatsfondse tans aan die provinsies toegedeel word. Die toedeling en administrasie van hierdie fondse sal die verantwoordelikheid van die kamers en hulle amptenare wees.

Oor twee baie belangrike meganismes waarvoor in die nuwe konstitusie voorsiening gemaak word, is nog niks gesê nie. Hierdie meganismes is die Presidentsraad en die permanente gesamentlike komitees.

\section{Die Presidentsraad}

Die instelling van die Presidentsraad is 'n poging om vir vakkundigheid in die beleidsproses voorsiening te maak. Daarmee sluit die nuwe konstitusie by 'n tendens aan wat die afgelope aantal jare die meeste Westerse demokrasieë kenmerk, naamlik om op 'n gekoördineerde en strukturele wyse vakkundiges by regeringsprosesse te betrek.

Dit spreek vanself dat die Presidentsraad sy funksie alleen goed sal kan vervul indien daarvan nie ' $n$ stal vir moeë en uitgediende perde gemaak word nie! Via die Presidentsraad sal dit byvoorbeeld vir die privaatsektor en ander belangelangegroepe moontlik wees om insette te maak.

Die funksie van die Presidentsraad sal hoofsaaklik adviserend van aard wees. In bepaalde gevalle, wanneer daartoe deur die President versoek, kan die Presidentsraad ook 'n skeidsregterfunksie vervul veral wanneer dispute tussen die kamers ontstaan. 


\section{Permanente Gesamentlike Komitees}

Die skrywer meen dat die permanente gesamentlike komitees van die belangrikste meganismes van die nuwe bedeling is. Daarmee sluit ons ook by ' $n$ ontwikkeling aan wat ons in Wes-Duitsland en die Verenigde State vind en wat ons reeds in die huidige bedeling die afgelope aantal jare het.

Hierdie meganisme is belangrik omdat ons moet aanvaar dat eie sake nie in waterdigte hokkies kan bestaan nie. Eie sake sal bowendien aan algemene beleid en algemene wetgewing onderhewig wees. Dat dit voor die hand liggend is, hang onder andere saam met die feit dat eie sake van een bevolkingsgroep ook raakpunte met die eie sake van ander bevolkingsgroepe sal hê.

Alhoewel gesondheidsdienste byvoorbeeld as 'n eie saak gedefinieer is, moet aanvaar word dat dit onderhewig sal wees aan algemene gesondheidsbeleid en algemene gesondheidswetgewing. 'n Kamer sal nie willekeurig sy eie gesondheidsbeleid kan formuleer nie. Daar sal dus ook samewerking en samesprekings tussen die onderskeie kamers moet wees.

Die permanente gesamentlike komitees, waarop alle partye in die drie kamers verteenwoordig sal wees, sal onder andere in hierdie noodsaaklike behoefte voorsien. Die skrywer voorsien trouens ook dat op streeks- en plaaslike vlak netwerke van samesprekings- en samewerkingsliggame sal ontstaan waar verteenwoordigers van die verskillende bevolkingsgroepe insette kan maak.

Die permanente gesamentlike komitees is ook om 'n ander rede belangrik. In die soeke na konsensus sal hierdie komitees 'n belangrike rol speel. Omdat die besprekings nie in die openbaar sal geskied nie, is die kanse beter dat 'n mate van eenstemmigheid bereik sal word. Ons kan daarom hierdie komitees as belangrike instrumente in die proses van onderhandeling beskou.

\section{Die President}

Die nuwe konstitusie maak ook daarvoor voorsiening dat die regeerproses nie ernstig gekortwiek of aan bande gelê sal word nie. Daar is, om dit so te stel, ' $n$ aantal brandtrappe in die nuwe konstitusie ingebou wat sal waarborg dat besluitneming nie vasloop en tot stilstand gebring word nie. 'n Staat moet immers regeer word. Besluitneming, veral oor belangrike kwessies, moet kan voortgaan. So nie, word 'n belangrike vereiste vir 'n gesonde staatshuishouding, naamlik stabiliteit, in die gedrang gebring.

Een so 'n brandtrap is die soort funksie wat aan die President toegeken is - byvoorbeeld in gevalle wanneer 'n dispuut tussen die kamers ontstaan.

Die skrywer twyfel nie dat die President dié sleutelfiguur in die nuwe bedeling sal wees nie. Sy persoonlikheid, leierskap en vernuf om as arbiter én versoener, onderhandelaar en uitvoerder van gesag op te tree, sal 'n belangrike voorwaarde vir die suksesvolle werking van die nuwe konstitusie wees. Hy sal alles in sy vermoë moet doen om die vertroue van die deelnemende partye, veral die meerderheidspartye in die verskillende kamers, te werf. Aangesien hy die voorsitter sal wees van die kabinet wat die Staatsdepartemente vir algemene sake sal administreer, en wat sal bestaan uit persone wat deur hom aangewys is, is hy wel in 'n posisie om vertroue te werf.

Die persone wat hy aanwys, moet lid van een van die kamers wees of binne twaalf maande ' $n$ lid word. Op hierdie wyse word daar ook 'n band tussen die uitvoerende gesag en die wetgewende gesag gelê.

Die skrywer is ook nie een van diegene wat meen dat die President met diktatoriale magte beklee is nie. Diktators regeer gewoonlik lewenslank, tensy hulle deur die weermag uitgeskakel of selfs geskiet word. Die President in die nuwe bedeling word gekies - en boonop vir 'n termyn. Enige persoon wat verkies word, en wat ook herverkies wil word, kan nie maak wat hy wil nie. Kortom, die President is wel aan formele en informele beperkinge onderhewig.
Wat ons wel in die nuwe bedeling vind, is ' $n$ versterking van die uitvoerende gesag. Dit is in 'n heterogene samelewing, en bowendien 'n samelewing wat op hervorming gerig is, noodsaaklik.

In die lig van die voorafgaande kan ons nou let op 'n paar moontlike implikasies van die nuwe bedeling.

\section{IMPLIKASIES}

\section{Administrasie}

Die eerste implikasie het betrekking op die administrasie van die land en vloei voort uit die onderskeiding tussen algemene en eie sake.

Soos reeds gesê, sal die President bygestaan word deur 'n kabinet. Die ministers van hierdie kabinet sal hoofsaaklik aan die hoof van Staatsdepartemente vir algemene sake staan. Daar sal dus 'n administrasie vir algemene belange wees en hierdie administrasie resorteer direk onder die President en sy kabinet. Dit dien ook vermeld te word dat die nuwe kabinet ook ministers sal kan insluit wat nie aan die hoof van 'n Staatsdepartement staan nie.

Benewens die administrasie vir algemene sake, sal daar ook administrasies vir eie sake wees, of te wel Staatsdepartemente vir gemeenskapsbelange. Aan die hoof van hierdie Staatsdepartemente sal Ministers staan wat lede is van die Ministersrade van die onderskeie kamers. So 'n Minister moet lid van die betrokke bevolkingsgroep wees, lid van die kamer van daardie bevolkingsgroep wees of binne twaalf maande word, en na die oordeel van die President die steun van die meerderheid van die betrokke kamer geniet. Dit sal dus nie kan gebeur dat 'n blanke as minister aan die hoof van 'n Staatsdepartement wat 'n eie saak van byvoorbeeld die bruinmense hanteer, kan staan nie.

\section{Desentralisasie van magte}

'n Tweede belangrike implikasie is dat die nuwe bedeling ' $n$ desentralisasie van magte in die hand sal werk en, gepaardgaande daarmee, tot streeksverdeling aanleiding sal gee.

Vervolg op p. 20 